\title{
PENINGKATAN KOMPETENSI SISWA MELALUI PELATIHAN AUTO CAD
}

\author{
Remon Lapisa ${ }^{1 *}$, Irma Yulia Basri ${ }^{1}$, Ahmad Arif ${ }^{1}$, Hendra Dani Saputra ${ }^{1}$ \\ ${ }^{1}$ Jurusan Teknik Otomotif, Fakultas Teknik, Universitas Negeri Padang \\ *e-mail: remonlapisa@yahoo.com
}

\begin{abstract}
Abstrak - Siswa-siswa SMK membutuhkan beberapa keahlian yang nantinya akan digunakan ketika siswa menyeleseikan studinya di sekolah. Salah keahlian yang diharapkan adalah kemampuan menggambar menggunakan program Auto Cad. Dimana kemampuan akhir yang diharapkan dari siswa nantinya adalah mampu membuat gambar dalam bentuk model 2-D dan 3-D. Tujuan dari program pelatihan adalah untuk mengembangkan dan meningkatkan kemampuan dari siswa kelas XII dalam menggunakan program Auto Cad. Dengan program pelatihan ini diharapkan siswa mampu membuat gambar komponen-komponen mesin dalam bentuk format 2-D dan 3-D. Sehingga siswa kelas XII SMK memiliki kemampuan menggambar komponen-komponen mesin dan gambar-gambar lainnya dalam format 2-D dan 3-D. Program pelatihan ini menggunakan metode melaui pemberian modul Auto Cad, diskusi, menayangkan melalui slide cara pembuatan gambar mesin dalam format 2-D dan 3-D serta mempraktekkan cara membuat gambar 2-D dan 3-D. Sehingga diharapkan terjadi peningkatan kemampuan siswa kelas XII dalam menggambar komponen-komponen mesin dan gambar-gambar lainnya dalam format 2-D dan 3-D.
\end{abstract}

Kata kunci: Auto Cad software, pelatihan, siswa

\begin{abstract}
SMK students need some skills that will be used when students are finishing the study at school. One of the skill that is expected is the ability to draw using Auto Cad program. Where the final ability expected of students will be able to create images in the form of 2-D and 3-D models. The purpose of the training program is to develop and improve the ability of the XII class students in using Auto Cad program. With this training program students are expected to be able to draw machine components in the form of 2$D$ and 3-D format. So that the students of class XII SMK have the ability to draw engine components and other pictures in 2-D and 3-D format. This training program uses the method through Auto Cad module, discussion, slide shows how to make machine drawing in 2-D and 3-D format and practice how to create 2$D$ and 3-D images. So it is expected to increase the ability of class XII students in drawing machine components and other images in 2-D and 3-D format.
\end{abstract}

Keywords: Auto Cad software, training, students

Copyright @ 2017 INVOTEK. All rights reserved

\section{Pendahuluan}

Salah satu program yang dicanangkan oleh pemerintah melalui kementrian pendidikan dan kebudayaan adalah program SMK bisa. Melalui program SMK bisa pemerintah berharap dapat menciptakan tenaga-tenaga kerja siap pakai.

Oleh karena itu pemerintah berupa menambah jumlah SMK baik SMK negeri maupun SMK swasta. Peningkatan jumlah SMK tidak dibarengi dengan peningkatan kulaitas lulusan dari SMK tersebut. Masih banyak ditemui siswa SMK yang tidak bekerja setelah lulus dari SMK. Salah satu kekurangan yang ditemui adalah kurangnya kompetensi siswa dalam menggunakan komputer. Khususnya dalam jurusan teknik kendaraan ringan, lulusan SMK masih banyak yang belum mahir dalam menggunakan program Auto Cad.

Kemampuan menggunakan Auto Cad bagi siswa kelas XII jurusan teknik kendaraan ringan (TKR) sangat dibutuhkan ketika mereka bekerja di dunia industri. Dunia usaha dan dunia industri saat ini dalam merancang bodi dan komponen-komponen mesin menggunakan salah satunya program menggambar dengan Auto Cad. Sehingga gambar bodi dan komponen-komponen mesin lainnya dapat dilihat secara nyata (3-D). Sehingga siswa yang sudah bisa menggunakan program Auto Cad sangat diminati dan mendapat perhatian lebih oleh dunia usaha dan dunia industri.

SMK dalam hal ini menyadari perlunya penyesuain kompetensi-kompetensi lulusannya 
dengan dunia usaha dan dunia industri. Namun beberapa kendala yang sering dihadapi SMK adalah, masih kurangnya labor komputer dan jumlah komputer yang dapat digunakan untuk pratikum Auto Cad. Sehingga siswa kelas XII tidak dapat belajar maksimal dan optimal dalam program Auto Cad.

Salah satu SMK yang penulis jadikan observasi adalah SMK di Kabupaten Tanah Datar. Khususnya SMK Negeri 1 Batipuh dan K Muhammadiyah Batusangkar. Pada sekolah ini hanya terdapat satu laboratorium komputer. Penggunaaan laboratorium ini hanya dapat dipergunakan ketika jam pembelajaran komputer. Tentu hal ini menjadi kurang maksimal dan optimal, idealnya tiap-tiap jurusan di SMK ada satu laboratorium khusus komputer masing-masing. Sehingga siswa-siswa SMK khususnya kelas XII dapat belajar pengoperasian program Auto Cad dengan optimal dan maksimal.

Disamping itu, penggunaan laboratorium yang ada terbatas hanya pada pembelajaran dan penguasaan serta pengoperasian MS.office. Khusus untuk siswa kelas XII TKR belum ada mempelajari tentang bagaimana car mengoperasikan dan menggunakan program Auto Cad. Kemampuan Auto Cad sangat dibutuhkan dalam dunia usaha dan industri. Kemampuan Auto Cad ini, khususnya menggambar 2-D dan 3-D diperlukan dalam merancang bodi, mesin dan keseluruhan komponen-komponen yang ada pada kendaraan.

Design gambar mengunakan Auto Cad lebih efektif dan efisien dibandingkan dengan cara konvensional. Hasil design Auto Cad lebih akurat dan mudah dalam modifikasi. Disamping itu, penggunaan laboratorium yang ada terbatas hanya pada pembelajaran dan penguasaan serta pengoperasian MS.office. Khusus untuk siswa kelas XII TKR belum ada mempelajari tentang bagaimana car mengoperasikan dan menggunakan program Auto Cad. Kemampuan Auto Cad sangat dibutuhkan dalam dunia usaha dan industri. Kemampuan Auto Cad ini , khususnya menggambar 2-D dan 3-D diperlukan dalam merancang bodi, mesin dan keseluruhan komponen-komponen yang ada pada kendaraan.

Design gambar mengunakan Auto Cad lebih efektif dan efisien dibandingkan dengan cara konvensional. Hasil design Auto Cad lebih akurat dan mudah dalam modifikasi.

Kebutuhan penguasaan sofware Auto Cad sangat penting bagi siswa kelas XII. Ketika lulus dari SMK nantinya, kemampuan ini menjadi salah satu syarat wajib jika ingin bergabung dengan perusahaan. Banyak perusahaan mencantumkan syarat untuk bergabung bagi lulusan SMK harus menguasai komputer dalam hal MS. Office dan Auto Cad.

Melalui kegiatan pengabdian kepada masyarakat yang diselenggarakan oleh UNP, maka penulis tertarik untuk memberikan Pelatihan Menggambar Teknik Menggunakan Komputer (Auto Cad) di SMK di Kabupaten Tanah Datar, dalam hal ini pesertanya dari SMK Negeri 1 Batipuh dan SMK Muhammadiyah Batusangkar sebanyak 20 orang. Khusus pesertanya diutamakan bagi siswa kelas XII jurusan Teknik Kendaraan Ringan. Pelatihan dimulai dari penguasaan tingkat dasar, perancangan gambar 2-D dan dilanjutkan dengan gambar 3-D. Dengan pelatihan ini diharapkan nantinya terjadi peningkatan kompetensi siswa kelas XII dalam mengoperasikan program Auto Cad. Sehingga siswa-siswa kelas XII jika lulus nantinya dapat langsung bekerja.

\section{Studi Pustaka}

\section{A. Kompetensi Siswa}

Kompetensi diartikan sebagai pengetahuan, keterampilan, dan kemampuan yang dikuasai oleh seseorang yang telah menjadi bagian dari dirinya, sehingga dapat melakukan perilakuperilaku kognitif, afektif, dan psikomotor dengan sebaik-baiknya.

Kompetensi mencakup tugas, keterampilan, sikap, dan apresiasi yang harus dimiliki oleh siswa agar dapat melaksanakan tugas-tugas yang dipelajarinya di sekolah sesuai dengan kemampuan yang diperlukan oleh dunia kerja

Kompetensi yang harus dikuasai oleh siswa, yang dapat dijabarkan dalam: kompetensi dasar untuk setiap mata diklat, pokok-pokok materi yang harus disampaikan untuk mencapai kompetensi tersebut. Indiktor tercapainya kompetensi, yang secara keseluruhan dapat diaplikasikan dalam kegiatan pembelajaran dengan fleksibel dan adaptable sesuai kondisi serta kebutuhan setempat, baik kebutuhan siswa maupun kebutuhan masyarakat, sehingga memberikan ruang bagi guru untuk melakukan manuver dan inovasi guna mencapai pembelajaran yang efektif, efisien, dan relevan.

Penjabaran kompetensi ini dijelaskan pada Jurnal Penelitian dan Evaluasi Pendidikan, Nomor 2, Tahun X, 2007, Halaman 268-278 oleh Widihastuti dengan judul Pencapaian Standar Kompetensi Siswa SMK Negeri Program Keahlian Tata Busana Di Kota Yogyakarta Dalam 
Pembelajaran Dengan KBK. Hasil penelitian menunjukkan:

(1) Tingkat keefektifan pembelajaran dengan KBK ditinjau dari pencapaian standar kompetensi siswa dari nilai normatif termasuk tinggi dan telah memenuhi kriteria efektif $94,9 \%$ (>70\% siswa telah mencapai nilai $>7,0$ ), (2) Tingkat keefektifan pembelajaran dengan KBK ditinjau dari pencapaian standar kompetensi siswa dari nilai adaptif termasuk tinggi namun belum memenuhi kriteria efektif karena baru 66,4\% (<70\% siswa yang telah mencapai nilai $>7,0$ ), dan (3) Tingkat keefektifan pembelajaran dengan KBK ditinjau dari pencapaian standar kompetensi siswa dari nilai produktif termasuk tinggi namun belum memenuhi kriteria efektif karena baru 58,4\% (< 70\% siswa yang telah mencapai nilai $\geq 7,5$ ).

\section{B. Pembelajaran Auto CAD}

AutoCAD adalah perangkat lunak komputer CAD untuk menggambar 2 dimensi dan 3 dimensi yang dikembangkan oleh Autodesk. Keluarga produk AutoCAD, secara keseluruhan, adalah software CAD yang paling banyak digunakan di dunia. AutoCAD digunakan oleh insinyur sipil, land developers, arsitek, insinyur mesin, desainer interior dan lain-lain. Mata pelajaran AutoCAD dasar merupakan pelajaran yang berbasis progam komputer. Dimana mata pelajaran tersebut menggunakan kurikulum spectrum. Untuk kelancaran penggunaan progam ini, harus memaksimalkan daya tangkap siswa terhadap materi pelajaran AutoCAD Dasar. Untuk memperoleh hasil tersebut, maka salah satu alternatif adalah dengan cara membuat media pembelajaran pada mata pelajaran menggambar AutoCAD.

\section{METODE}

Penelitian ini merupakan penelitian Quasi Experiment dengan menggunakan pendekatan kuantitatif. Populasi penelitian meliputi 20 orang siswa Program Keahlian TKR SMK Negeri 1 Batipuh dan SMK Muhammadiyah Batusangkar. Data penelitian dikumpulkan dari hasil pre-test dan posttest pencapaian standar kompetensi siswa terhadap pelatihan yang diberikan. Teknik analisis data yang digunakan adalah teknik analisis data statistik deskriptif .

\section{HaSil dan PEMBahasan}

\section{A. Permasalahan Mitra}

Kompetensi siswa SMK di Kabupaten Tanah Datar perlu ditingkatkan, terutama dalam penguasaan perangkat lunak Auto Cad. Diharapkan lulusan siswa SMK di Kabupaten Tanah Datar lebih siap bersaing dalam memasuki dunia kerja. Minimal lulusan siswa SMK Negeri 1 Batipuh dan SMK Muhammadiyah Batusangkar dapat memenuhi dan lolos syarat administrasi serta syarat wajib mampu mengoperasikan MS.Office dan Auto Cad. Melalui pengabdian masyarakat ini, diharapkan siswa SMK Negeri 1 Batipuh mempunyai kemampuan dasar mengoperasikan Auto Cad dan siswa mampu merancang gambar 2d dan 3-D. Melalui pelatihan ini, diharapkan siswa SMK nantinya bisa langsung bekerja di dunia usaha dan dunia industri serta mampu mengembangkan kemampuannya tidak hanya dalam perancangan di bidang teknik, namun juga dalam bidang kehidupan lainnya.

\section{B. Tujuan}

Kegiatan pengabdian masyarakat bertujuan untuk mengembangkan dan menyukseskan pembangunan menuju tercapainya masyarakat yang maju, adil dan sejatera. Termasuk juga usaha untuk meningkatkan kemampuan masyarakat dalam sasaran pemecahan masalah sendiri.

Kegiatan pengabdian masyarakat harus selalu diarahkan pada kegiatan-kegiatan yang memberikan dampak dan manfaat langsung yang dirasakan masyarakat. Upaya ini dapat dilakukan dengan melakukan suatu penelitian yang memberikan penerapan,pengembangan dan penyebarluasan ilmu pengetahuan yang diperlukan di masyarakat.

Secara khusus tujuan pengabdian masyarakat dalam kegiatan ini adalah sebagai berikut:

a. Memotivasi siswa-siswa SMK di Kabupaten Tanah Datar untuk meningkatkan dan mengembangkan keterampilannya dalam bidang Auto Cad.

b. Melatih dan membimbing keterampilan para siswa SMK di Kabupaten Tanah Datar dalam menggambar dasar menggunakan perangkat lunak Auto Cad

c. Melatih dan membimbing siswa-siswa SMK di Kabupaten Tanah Datar dalam perancangan objek gambar 2-D dan 3-D. 


\section{Manfaat}

Kegiatan pengabdian masyarakat yang dilaksanakan, diharapkan mampu memberikan manfaat:

a. Terjadinya peningkatan kompetensi dan keterampilan siswa-siswa SMK di Kabupaten Tanah Datar dalam bidang mengoperasikan perangkat lunak Auto Cad

b. Terjadinya peningkatan keterampilan siswasiswa SMK di Kabupaten Tanah Datar dalam perancangan dan menggambar objek 2-D dan 3-D

c. Meningkatkan rasa percaya diri siswa-siswa SMK di Kabupaten Tanah Datar dalam menghadapi persaingan dalam dunia kerja

\section{Kerangka Pemecahan Masalah}

Salah satu bentuk kepedulian perguruan tinggi khususnya Universitas Negeri Padang kepada generasi penerus bangsa khususnya siswa SMK di kabupaten Tanah Datar, dengan memberikan pelatihan yang berguna untuk meningkatkan dan mengembangkan bakat para siswa. Melalui kegiatan program pengabdian kepada masyarakat dengan tema "Pelatihan Menggambar Teknik Menggunakan Komputer (Auto Cad) dalam rangka peningkatan kompetensi siswa SMK di Kabupaten Tanah Datar. Dalam kegiatan ini diwakili oleh SMK Negeri 1 Batipuh dan SMK Muhammadiyah Batusangkar.

Materi pelatihan dalam program pengabdian masyarakat ini, difokuskan pada kemampuan akhir para siswa untuk dapat melakukan perancangan gambar 2-D dan 3-D disertai dengan pemberian ukuran gambar. Program pelatihan ini didukung oleh laboratorium komputer SMK Negeri 1 Batipuh.

\section{E. Realisasi Pemecahan Masalah}

\section{Tahap Persiapan}

Survey dan observasi kepada guru-guru SMK di Kabupaten Tanah Datar khususnya jurusan Teknik Kendaraan Ringan. Dalam hal ini difokuskan kepada guru yang mengajar gambar

a. mesin, untuk mengidentifikasi permasalahan dan sasaran kompetensi yang akan dicapai.

b. Menyusun proposal oleh tim pelaksana

c. Merencanakan bidang pelatihan tentang pelatihan Auto Cad sesuai dengan kondisi di lapangan

d. Membuat program pelatihan
2. Realisasi Kegiatan

Kegiatan pelatihan dilaksanakan dari tanggal 26 s.d 27 Agustus 2017. Kegiatan dilaksanakan di Laboratorium SMK Negeri 1 Batipuh . Materi pelatihan yang diberikan mencakup: pengenalan Auto Cad, Commad Utility, Command menggambar, Command Editing, dan perancangan gambar 2-D dan 3-D.

\section{F. Metode Yang Digunakan}

1. Metode ceramah dan tanya jawab

Metode ini digunakan untuk menyajikan informasi umum tentang teori umum mengenai keunggulan Auto Cad, perbedaan masingmasing command utility, command menggambar dan commad editing. Auto Cad memerlukan penyajian gambar langsung, sehingga pada saat penyajian materi melalui slide powerpoint diikuti dengan demontrasi langsung menggunakan bantuan software Auto Cad.

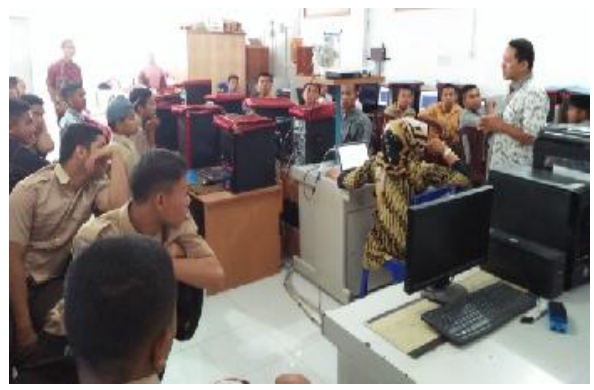

Gambar 1. Aktifitas kegiatan penyajian informasi tentang Auto Cad

2. Metode Demontrasi dan praktek langsung

Instruktur mendemontrasikan kepada peserta langkah-langkah perancangan dan pembuatan gambar 2-D dan 3-D melalui modul pelatihan yang diberikan kepada masingmasing peserta.

Setelah instruktur pelatihan selesai menyajikan materi, peserta diberikan kesempatan untuk berlatih dan melakukan perancangan serta pembuatan gambar 2-D dan 3 -D yang telah didemontrasikan oleh instruktur.

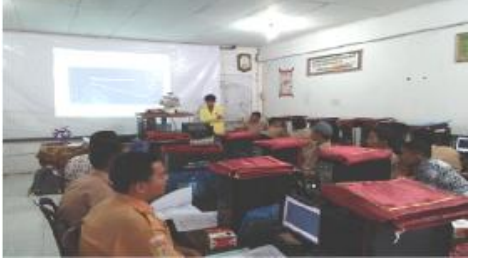

Gambar 2. Aktifitas kegiatan mendemontrasikan langkah-langkah perancangan gambar 2-D 


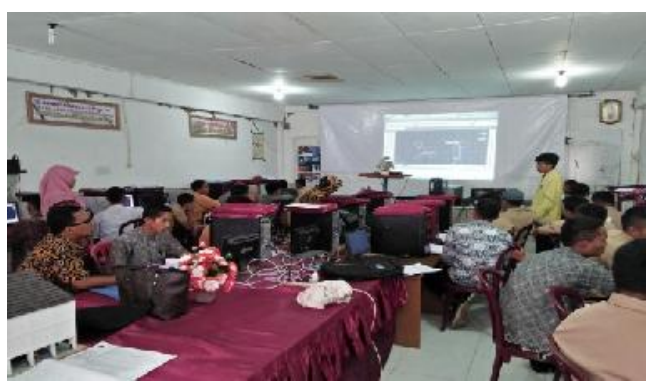

Gambar 3. Aktifitas praktek langsung perancangan gambar 2-D

\section{Metode Bimbingan}

Proses bimbingan dipandu langsung oleh panitia yang telah dibentuk oleh tim pengabdian masyarakat. Bimbingan dilakukan dan dipandu langsung dari kalangan dosen, teknisi labor, maupun mahasiswa . Hal ni bertujuan untuk memberikan pelayanan kepada peserta pelatihan. Sehingga target capaian yang direncanakan oleh tim pengabdian masyarakat dapat tercapai. Bimbingan yang dilakukan oleh tim pelaksana berjalan efektif dan sangat membantu peserta pelatihan, meskipun materi dipadatkan dalam waktu 2 hari. Hal ini dikarenakan keterbatasan laboraorium yang bisa diakses peserta pelatihan. Pada hari pembelajaran reguler yaitu senin -jumat laboratorium dipakai oleh siswa-siswa jurusan lain yang praktek khusus mata pelajaran komputer di laboratorium komputer
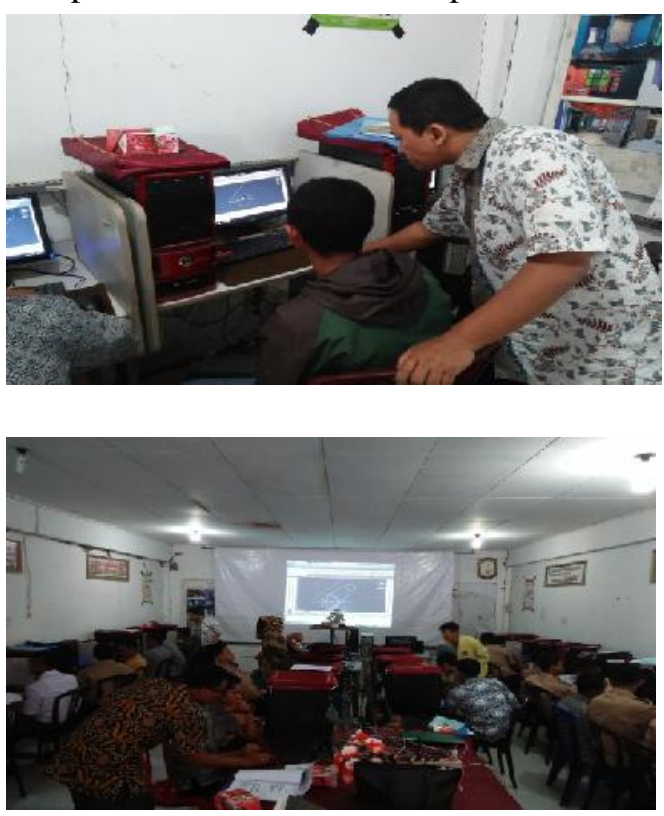

Gambar 4. Bimbingan langsung kepada peserta pelatihan

\section{G. Keluaran Pelatihan}

Luaran kegiatan pelatihan ini berupa jasa pelatihan , modul pelatihan perancangan gambar 2-D dan 3D menggunakan Auto Cad, dokumentasi kegiatan pelatihan, flash disk yang diberikan kepada peserta pelatihan yang digunakan untuk menyimpan data selama pelatihan.

1. Jasa pelatihan

Dalam pelaksanaan kegiatan pelatihan Auto Cad diharapkan mampu memberikan peningkatan kemampuan peserta pelatihan dari yang belum mengenal Auto Cad menjadi mampu membuat gambar rancangan format 2$\mathrm{D}$ dan 3-D menggunakan komputer dengan software Auto Cad

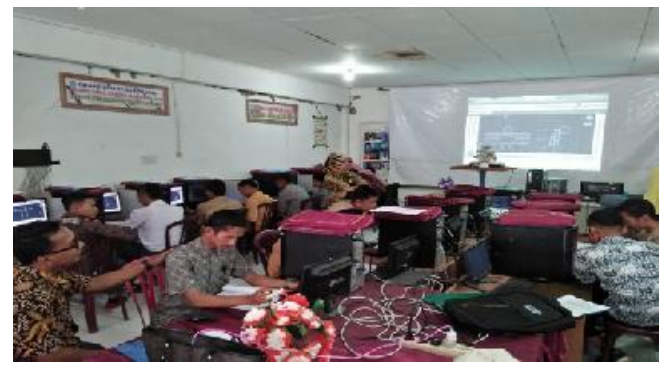

Gambar 5. Aktifitas kegiatan

2. Modul

Modul berisi langkah-langkah praktis yang bisa digunakan oleh peserta pelatihan. Modul ini dapat digunakan sebagai panduan dalam perancangan menggambar komponen mesin menggunakan komputer. Modul juga dilengkapai dengan tugas-tugas dan latihanlatihan yang bisa dikerjakan tidak hanya di laboratorium sekolah tetapi juga di rumah.

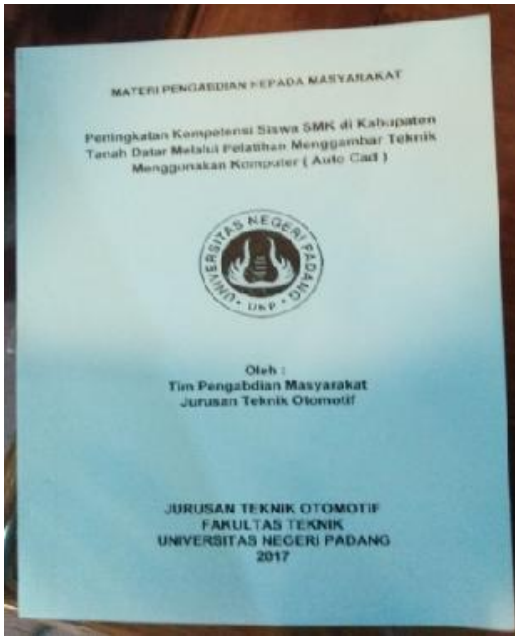

Gambar 6. Modul 


\section{H. Hasil dan Pembahasan}

1. Hasil

Untuk melihat hasil yang telah dicapai, dilakukan evaluasi saat kegiatan berlangsung. Evaluasi juga dilakukan pada akhir kegiatan pelatihan

a. Evaluasi saat kegiatan

\section{1) Kehadiran}

Jumlah peserta yang mengikuti pelatihan adalah 20 orang sesuai dengan yang direncanakan. Semua peserta dapat mengikuti pelatihan dari awal kegiatan samapai akhir kegiatan.

Pelatihan dipadatkan 2 hari sabtu-minggu mulai jam 08.00-18.00 WIB.

Meskipun pelatihan dilaksanakan pada hari sabtu dan minggu, peserta pelatihan tetap antusias dalam mengikuti pelatihan Auto Cad. Selama pelaksanaan pelatihan, tidak ada peserta yang tidak hadir atau berhalangan hadir .

Bahkan pada saat jam istirahat peserta masih antusias untuk menyeleseikan gambar rancangan yang sedang dibuat. Sehingga peserta pelatihan hanya sedikit mengambil waktu dari alokasi waktu istirahat yang disediakan oleh panitia.

2) Sikap dan Antusiasme peserta pelatihan Selama pelatihan berlangsung sikap dan antusiasme peserta pelatihan sangat tinggi. Hal ini dapat dilihat dari sikap peserta pelatihan yang tidak mau meninggalkan tempat pelatihan. Disamping itu peserta pelatihan juga disiplin dalam mematuhi jadwal yang telah ditetapkan oleh panitia. Peserta pelatihan masuk jam 08.00 WIB dan pulang jam 18.00 WIB.

Saat jam istirahat peserta pelatihan memanfaatkan waktu dengan membuat latihan yang ada di modul pelatihan. Ada beberapa peserta yang sudah selesai latihan 1 tanpa diinstruksikan panitia, langsung mengerjakan latihan 2 yang ada pada modul.

Panitia pelaksana pelatihan sangat kooeperatif dan saling mendukung aktifitas dari peserta pelatihan tersebut. Semua panitia terlibat aktif membantu dalam keterlaksanaan kegiatan pelatihan.

3) Keiingintahuan peserta pelatihan sangat tinggi
Hal ini dapat dilihat dari keseriusan peserta dalam mendengarkan materi dan melaksanakan perintah yang diberikan oleh instruktur. Peserta

pelatihan dapat melihat dan mempelajari modul yang diberikan, jika peserta pelatihan mempunyai kendala peserta pelatihan tidak ragu untuk bertanya pada instruktur.

Banyak peserta pelatihan yang belajar mandiri dari modul yang diberikan oleh panitia. Terdapat juga beberapa peserta pelatihan yang dapat mengerjakan latihan hanya dengan membaca dan memahami modul tanpa kendala yang berarti. Jika peserta pelatihan ada kendala, peserta pelatihan dapat bertanya kepada tim instruktur.

4) Tidak ada peserta pelatihan yang berdiam diri selama kegiatan berlangsung. Selama kegiatan peserta pelatihan aktif mengerjakan latihan dan tugas yang diberikan instruktur. Peserta pelatihan mampu menyeleseikan tugas yang diberikan . Beberapa peserta pelatihan yang cepat

menyeleseikan tugas yang diberikan instruktur, melakukan proses bimbingan serta bantuan kepada peserta-peserta lain yang belum menyeleseikan tugas yang diberikan instruktur pelatihan.

b. Evaluasi Akhir kegiatan

Dilakukan dengan melihat hasil akhir tugas yang dihasilkan oleh peserta pelatihan. Hasil akhir pserta pelatihan dievaluasi bagaimana ukuran gambar, bentuk gambar dan ukuran gambar yang diminta lakukan oleh instruktur pelatihan. Berdasarkan hasil observasi awal dan akhir kegiatan pelatihan yang dilakukan. Didapatkan hasil kemampuan pengetahuan dan keterampilan peserta pelatihan meningkat secara signifikan. Sebelum dilakukan pelatihan, semua peserta pelatihan belum memiliki kemampuan untuk membuat gambar pada komputer melalui program Auto Cad. Setelah diberikan materi dan dilakukan praktek langsung kepada peserta pelatihan, maka terdapat peningkatan kemampuan pengetahuan dan keterampilan peserta pealtihan. 
Untuk lebih jelas dapat dilihat dari pada gambar 7 berikut ini.

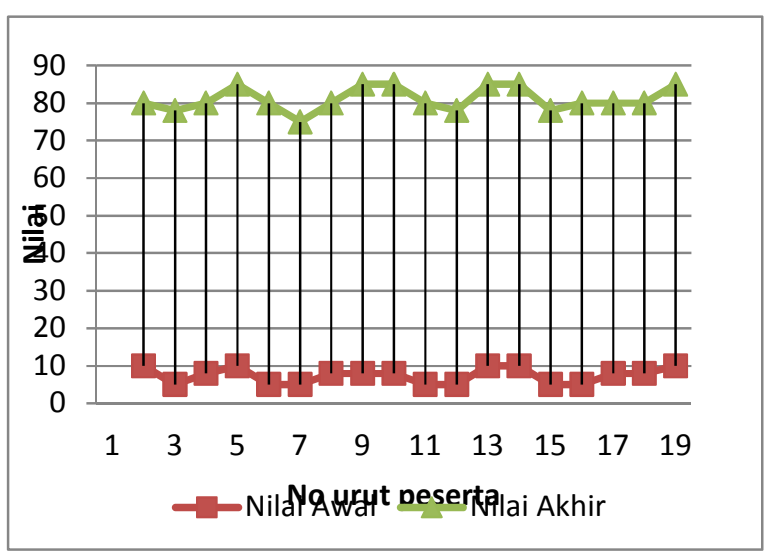

Gambar 7. Grafik peningkatan pengetahuan dan keterampilan siswa

Hasil kegiatan pelatihan ini, selain terjadi penambahan dan peningkatan kemampuan pengetahuan dan keterampilan. Kegiatan ini juga menghasilkan luaran berupa:

1. Masing-masing peserta mendapatkan satu modul pembelajaran berisi panduan lengkap dan gamabr latihan yang bisa di ujicobakan secara mandiri saat pelatihan berlangsung

2. Masing-masing peserta pelatihan mendapatkan 1 unit flsh disk 8 GB yang digunakan oleh peserta untuk menyimpan data hasil pelatihan.

\section{Pembahasan}

Sasaran kegiatan pelatihan ini dapat dicapai sesuai dengan yang diharapkan. Ini dapat dilihat dari hasil akhir nilai pengetahuan dan keterampilan yang telah diperoleh oleh peserta pelatihan. Peserta pelatihan mampu merancang gambar 2-D dan gambar 3-D. Peserta pelatihan juga mampu memodifikasi gambar 3-D sesuai dengan latihan yang diberikan. Selama pelatihan peserta mempunyai kedisplinan dalam mengikuti pelatihan. Peserta pelatihan juga memiliki percaya diri yang tinggi terhadap kemampuan yang telah mereka miliki. Hal ini terlihat dari antusiame peserta pelatihan yang semangat meminta software Auto Cad untuk bisa dipelajari mandiri di rumah. Peserta pelatihan juga berharap agar kegiatan pelatihan ini bisa diperpanjang, sehingga mereka bisa makin meningkatkan kemampuan gambar 2D dan 3-D. Karena keterbasan waktu, peserta pealtihan merasa perlu banyak waktu lagi untuk memantapkan keterampilan menggambar 2-D dan 3-D. Komunikasi antara instruktur dengan peserta pelatihan juga tidak terputus meskipun pelatihan sudah berakhir. Beberapa peserta pelatihan menghubungi instruktur untuk menanyakan beberapa kendala dalam peserta pelatihan temui dalam membuat gambar secara mandiri. Instruktu juga menyediakan waktu untuk membimbing peserta pelatihan baik melalui media sosial, telepon maupun peserta datang ke kampus.

\section{KeSimpulan}

Dalam kegiatan pelatihan Auto Cad yang diberikan kepada siswa SMK Negeri 1 Batipuh dan siswa SMK Muhammadiyah Batusangkar dapat disimpulkan:

Kegiatan pelatihan Auto Cad yang dilaksanakan pada tanggal 26 -27 Agustus 2017 dapat berjalan sesuai dengan rencana.

Hasil yang dicapai peserta pelatihan sesuai denga tujuan pelatihan yaitu utnuk meningkatkan pengetahuan dan keterampilan siswa SMK Negeri 1 Batipuh dan siswa SMK Muhammadiyah Batusangkar dibidang perancangan gambar 2-D dan 3-D.

\section{DAfTAR Pustaka}

[1] Chandra,handi (2004). AutoCAD 2004 Untuk Dasar. Jakarta: PT.Elexmedia Komputindo

[2] Darmawan, Djoko (2004). AutoCAD 20042 Dimensi. Jakarta: PT. Elexmedia Komputindo

[3] Yarwood (2002). Introduction to Autocad 2002. London: Pearson education

[4] Widihastuti, Jurnal Penelitian dan Evaluasi Pendidikan, Nomor 2, Tahun X, 2007, Halaman 268-278

\section{Biodata Penulis}

Remon Lapisa, lahir di Padang 18 September 1977. Sarjana Pendidikan di S1 - Teknik Mesin (Bahan dan Struktur), Universitas Gadjah Mada. S2 - Teknik Mesin (Konversi Energi), Universitas Indonesia S2 \& S3 - Genie Mecanique (Energies Renouvelables) Universite de la Rochelle. Staf pengajar di jurusan Teknik Otomotif FT UNP sejak tahun 2008- sekarang.

Irma Yulia Basri, dilahirkan di Solok 07 Juli 1977. Menyelesaikan S1 pada jurusan Pendidikan Teknik Elektronika dan pendidikan Pascasarjana (S2) Magister Pendidikan di S2 - Teknik Elektro, UGM Yogyakart.. Sejak tahun 2005 menjadi staf 
pengajar tetap di jurusan Teknik Otomotif Fakultas Teknik Universitas Negeri

Ahmad Arif, dilahirkan di Padang Panjang, 27 Februari 1989. Menyelesaikan S1 pada program studi Pendidikan Teknik Otomotif Jurusan Teknik Otomotif FT - UNP Padang tahun 2012 dan pendidikan Pascasarjana (S2) Magister Teknik di jurusan Teknik Mesin Program Pascasarjana ITS Surabaya dengan bidang konsentrasi Rekayasa Konversi Energi pada tahun 2015. Sejak tahun 2015 sampai sekarang menjadi staf pengajar di jurusan Teknik Otomotif FT - UNP.

Ahmad Arif, dilahirkan di Padang Panjang, 27 Februari 1989. Menyelesaikan S1 pada program studi Pendidikan Teknik Otomotif Jurusan Teknik Otomotif FT - UNP Padang tahun 2012 dan pendidikan Pascasarjana (S2) Magister Teknik di jurusan Teknik Mesin Program Pascasarjana ITS Surabaya dengan bidang konsentrasi Rekayasa Konversi Energi pada tahun 2015. Sejak tahun 2015 sampai sekarang menjadi staf pengajar di jurusan Teknik Otomotif FT - UNP.

Hendra Dani Saputra, saat ini aktif mengajar di Jurusan Teknik Otomotif Universitas Negeri Padang. Mendapatkan gelar S1 dan S2 dari Fakultas Teknik Universitas Negeri Padang. 